\title{
5 Breeding Approaches for Improved Genotypes
}

Orchids are highly priced in the international market due to their designed spectacular flowers, brilliant colours, delightful appearance, myriad sizes, shapes, forms, and long lasting qualities. The majesty of nature is represented in the most highly evolved family among monocotyledons: orchidaceae. The orchids with their 25,000 to 30,000 species in some 700 to 800 genera constitute the largest family among flowering plants, and exhibit almost innumerable hybrids and inexhaustible varieties.

\subsection{Cytogenetics}

From the beginning of orchid cytology, conceptions of the chromosome numbers in the family of orchidaceae have changed remarkably. Investigations conducted by Guignard (1982) and Strasburger (1888) observed that an orchid plant has a constant number of chromosomes in reproductive cells. They suggested 16 as a common number of chromosomes for orchids found in reproductive cells of Gymnadenia conopsea, Himantoglossum hircinum, Listera ovata, Orchis maculata and Paphiopedilum barbatum. Singh and Prakash (1995) reported that the basic numbers and somatic chromosome number show wide variation in orchidaceae; the lowest chromosome number is $2 \mathrm{n}=10$ (Oncidium pusillum) and the highest is $2 \mathrm{n}=200$ (Aeringes spp.). According to Duncan (1959), in different species and hybrids of orchids chromosome number in meristem (2n) varies: Cypripedium (20-22), Phragmipedium (20-32), Paphiopedilum (26-70), Ophrys (36), Orchis (20-80), Daclyorchis (20-120), Platanthera (16-126), Gymnadenia (16-80), Habenaria (2842), Listera (32-42), Epipactis (24-40), Cephalanthera (32-36), Goodyera (28-42), Liparis (30-42), Epidendrum (40-160), Cattleya (40-102), Laelia (40-60), Laeliocattleya (40-100), Brassocattleya (40-80), Dendrobium (38-80), Cymbidium (32-80), Oncidium (28-56), Aerides (38-40), Vanda (28-95), and Phalaenopsis (38-114).

Triploids are apparently most desirable in commercial Paphiopedilum (Duncan, 1947), Cattleya (Kamemoto, 1950) and Vanda (Storey, 1952). In Cymbidium, triploid and tetraploid hybrids allow for improved flower quality (Mehlquist, 1952; Meninger, 1954; Wells, 1956). A pentaploid (Wimber, 1954) and several polysomic individuals (Wimber and Hernlud, 1955) have also been reported in Cymbidium. In Vanda, diploid and tetraploid species and their hybrids, as well as polyploidy hybrids which have an origin independent of these species, form a hybridization array which extends through pentaploidy (Duncan, 1959).

\subsection{Pollination and Fertilization}

The morphological structure of orchid flower prevents easy fertilization. Moreover, the lumps of pollen they produce cannot be carried by wind. In nature, insects are usually 
the pollinators of flowers, but birds are involved in some species. Insects such as bees, moths, butterflies, beetles, ants, flies etc. enter into the lip, search out the nectar, release the cap and pollen masses and lodge on the head. While visiting another flower, the pollinia are pressed against the stigmatic surface. The grains germinate: the pollen tube penetrates the ovary and fertilize the ovules. Male bees are responsible for pollination of many orchids, e.g., Catasetum, Cycnoches, Gongora, Orchis. Butterflies and moths also help in the pollination process. Epidendrum secundatum is pollinated by butterflies attracted by the nectar. Moths usually pollinate white or light coloured flowers which emit strong odours at night (Bose and Bhattacharjee, 1980). Epipactis consmilis is reported to mimic the shape and colour of aphids, which attracts aphidophagous hoverflies for pollination. Flowers of Oncidium and Ophrys are attracted and pollinated by territory defending male Centries bees. Flowers of Cypripedium and Paphiopedilum have pouches, and if by chance insects enter into the structure, they must disturb the pollens and fertilization occurs before coming out of the flower. Self pollination occurs in Cypripedium schlmii, Neottia spp., Phaius grandiflorus etc. because of their inherent structural arrangements which facilitates pollination and fertilization (Bose, et al, 1999).

\subsection{Natural Hybridization}

The presence of natural hybrids evolved from crosses between the species in the wild has been recognized since the early days of orchid collection and cultivation. Phalaenopsis intermedia, collected from Philippines, is one of the oldest natural hybrids between P. aphrodite and P. rosea described correctly by Lindley in 1853. Natural hybridization within the genus Platanthera in North America occurred between the closely related species P. dilatata, P. hyperborea, P. limosa, P. sparsiflora and P. stricta. Two Masdevallia species, $M$. splendida and $M$. parlaloreana are recognized as natural hybrids developed from crosses between $M$. veitchiana and $M$. barlaeana which existed in the Andes of Peru. There are also records of inter-generic hybrids evolved under natural conditions and Laleliocattleya elegans is one of such examples (Bose et al, 1999).

A natural hybrid population of Oncidium arising out of a cross between Onc. staevi and Onc. jonesianum has also been reported. Veitch and Sons (1887-1894) described a complex of natural hybrids among Mexican and Columbian Odontoglossums. At least four different groups of hybrids viz. the crispo-odoratum group, crispo-lindleyanum group, crispo-luteopurpureanum group and triumphante-prescatoria group are recognized (Abraham and Vatsala, 1981). Natural interspecific hybrids have been reported in Cattleya, Laelia, Miltonia etc. Cattleya guatemalensis, collected by Skinner from Guatemala in 1861, was later found to be a natural hybrid between two species from different genera. It was developed from a cross between Epidendrum auranticum and Cattleya skinneri. At present, this natural hybrid is known under the generic name Epicattleya. In Brazil, Laelio-cattleya elegans came into existence from a natural cross 
between Laelia purpurata and Cattleya guttata, while, Laeliocattleya scilleriana is also a natural cross between Laelia purpurata and Laelia intermedia. Another interspecific natural hybrid Cattleya intricata developed from a cross between $C$. intermedia and C. leopoldii. One of the most interesting inter-generic natural hybrids spotted in the wild evolved from a cross between Cattleya warneri and Brassovola tuberculata. Two natural hybrids are also reported in the genus Ophrys from central Italy. The earliest known orchid hybrid appears to be Gymnadenia conopsea x Nigritella nigra found in Alps near Grenoble in 1987 and was described by Villars under the name Orchis suaveolens.

\subsection{Artificial Hybridization}

Orchid growers all over the world have developed crosses between different species and hybrids with varying degrees of success. Mr. John Dominy was the first successful orchid hybridist, who made a cross between Calanthe masuca and Calanthe furcata which flowered in the year 1856 for the first time. The hybrid was named as Calanthe $\mathrm{x}$ Domini in honour of its breeder, the first artificially raised hybrid to flower. William Herbert, Dean of Manchester, attempted orchid breeding and was the first person to take a crossed capsule to maturity from a cross between Orchis and Ophrys. He likely raised few seedlings but they perished after few days (Lenz and Wimber, 1959). John Dominy, in twenty years after his first success, actively engaged in orchid hybridization and was reported to develop at least 25 hybrids. It was only after the discovery of Professor Knudson that orchid seeds could be germinated in vitro, that production of orchid hybrids gained its momentum.

The orchid hybrids are offspring derived from the cross between two genetically non-identical individuals. Intraspecific, intragenic and intergeneric hybrids have been obtained in this group of plants. These hybrids have been recorded and registered by Rolfe and Hurst (1909) and by Messers. Sanders (1946 and addenda). Inter-generic crosses are very common in orchids and a large number of crosses involving two genera (bi-generic), three genera (trigeneric), four genera (tetra-generic), five genera (penta generic) hybrids are registered and listed (De and Bhattacharjee, 2011).

\subsubsection{Bigeneric Hybrids}

Aerdachnis $=$ Aerides $x$ Arachnis

Aeridocentrum $=$ Aerides $x$ Ascocentrum

Aredopsis $=$ Aerides $x$ Phalaenopsis

Ansidium $=$ Anselia $x$ Cymbidium

Aredovand $a=$ Aerides $x$ Vanda

Aranda $=$ Arachnis $x$ Vanda 
Aranthera $=$ Arachnis $x$ Renanthera

Ascocenda $=$ Ascocentrum $\times$ Vanda

Brassolaelia $=$ Brassovola $\times$ Laelia

Doritaenopsis $=$ Doritis $x$ Phalaenopsis

Epicattleya = Epidendrum $x$ Cattleya

Epilaelia $=$ Epidendrum $x$ Laelia

Laeliocattleya = Laelia $\times$ Cattleya

Miltonidium $=$ Miltonia $\times$ Oncidium

Odontocidium $=$ Odontoglossum $x$ Oncidium

Odontonia $=$ Odontoglossum $\times$ Miltonia

Renades $=$ Renanthera $x$ Aerides

Renanopsis $=$ Renanthera $x$ Vandopsis

Renancentrum $=$ Renanthera $\times$ Ascocentrum

Renantand $a=$ Renanthera $x$ Vanda

Renanthopsis $=$ Renanthera $\times$ Phalaenopsis

Rhynchovanda = Rhyncostylis $x$ Vanda

Sophrocattleya $=$ Sophronitis $x$ Cattleya

Sophrolaelia $=$ Sophronitis $x$ Laelia

Vandoritis $=$ Vanda $\times$ Doritis

\subsubsection{Trigeneric Hybrids}

Brassolaeliocattleya $=$ Brassavola $x$ Laelia $x$ Cattleya Colmanara $=$ Miltonia $\times$ Odontoglossum $\times$ Oncidium Dekensara = Brassovola $\times$ Cattleya $\times$ Schomburgkia Dialaeliocattleya $=$ Diacrinum $x$ Laelia $x$ Cattleya Epilaeliocattleya = Epidendrum $\times$ Laelia $\times$ Cattleya Hartara $=$ Broughtonia $\times$ Laelia $\times$ Sophronitis Laeliocattkeria = Laelia $\times$ Cattleya $\times$ Barkeria Laycockara $=$ Arachnis $x$ Phalaenopsis $x$ Vandopsis Lowara $=$ Brassavola $x$ Laelia $\times$ Sophronitis Lyonara = Cattleya $\times$ Laelia $\times$ Schomburgkia Mizulara $=$ Cattleya $\times$ Diacrinum $\times$ Schomburgkia Moirara $=$ Phalaenopsis $x$ Renanthera $x$ Vanda Mokara = Vanda $x$ Arachnis $x$ Ascocentrum Nakamotora $=$ Ascocentrum $\times$ Neofinetina $\times$ Vanda Osmentara = Broughtonia $\times$ Cattleya $\times$ Laeliopsis Rhyndoropsis = Rhyncostylis $x$ Doritis $x$ Phalaenopsis Sappanara $=$ Arachnis $x$ Phalaenopsis $x$ Renanthera Sophrolaeliocattleya $=$ Sophronitis $x$ Laelia $x$ Cattleya Trevorara $=$ Arachnis $x$ Phalaenopsis $x$ Vanda 
Vascostylis $=$ Vanda $x$ Ascocentrum $x$ Rhyncostylis

Wilsonara $=$ Cochlioda $x$ Odontoglossum $x$ Oncidium

Yapara $=$ Phalaenopsis $x$ Rhyncostylis $x$ Vanda

\subsubsection{Tetrageneric Hybrids}

Iwanagara $=$ Brassavola $\times$ Cattleya $\times$ Diacrinum $x$ Laelia

Kirchara $=$ Cattleya $\times$ Epidendrum $\times$ Laelia $\times$ Sophronitis

Potinara $=$ Brassavola $\times$ Cattleya $\times$ Laelia $\times$ Sophronitis

Recchara $=$ Brassavola $\times$ Cattley $\times$ Laelia $\times$ Schomburgkia

Withnearara $=$ Aspasia $\times$ Miltonia $\times$ Odontoglossum $\times$ Oncidium

Yamadara $=$ Brassavola $\times$ Cattley $\times$ Epidendrum $\times$ Laelia

\subsubsection{Pentageneric Hybrids}

Goodlera $=$ Brassia $\times$ Cochlioda $\times$ Miltonia $\times$ Odontoglossum $\times$ Oncidium

Hasegawara $=$ Cattleya $\times$ Brassavola $\times$ Broughtonia $\times$ Laelia $\times$ Sophronitis

\subsubsection{Hexageneric Hybrids}

Brilliabdera $=$ Aspasia $\times$ Brassia $\times$ Cochlioda $\times$ Odontoglossum $\times$ Oncidium $\times$ Miltonia

It is not possible to make crosses between any two genera, though free breeding is common in orchids. The majority of the success in orchid breeding was brought out by the art of patient breeding, intuition and perseverance of the orchid breeders and on several occasions merely by luck (Arditti, 1992). It requires several years to raise progeny from seeds to flowering stage. Unlike other crops, orchid seeds can not be germinated without special facilities. It takes a long time for the seeds to mature. Moreover, the number of seeds produced in a capsule is so high that to get a representative sample of the progeny that will be required to draw any valid genetic inferences will be very large and may be impossible on most occasions. Hence, information on combining ability and inheritance of characteristics in orchids is scanty.

\subsection{Mutagenesis}

Hybridization technology has proven very reliable and easy to use and has produced a wide range of successful cultivars with attractive combinations of spray length, bud number, flower colour and form, vase life, fragrance, seasonality and compactness. 
By introducing mutagenesis, however, wide variations of flower colours, form, and size can still be obtained in addition to overcoming incompatibility and sterility. In addition, complementary use of molecular techniques will allow breeders to target more specific characteristic changes and cut short breeding time. PCR-based techniques used to analyse the DNA of mutagenic clones found polymorphic fragments that can be developed as molecular markers (Basiran et al, 2002).

\subsection{Breeding Objectives}

The breeder's goal is to produce commercially important hybrids that have market demand and are liked by the consumers. The concept behind development of hybrids in orchids may vary according to the genus and species. The generalized objectives as stated by Bhattacharjee and Das (2008) are given below:

- To breed for better colour, size, and substance of the flower.

- To introduce perfect blending of colours in sepals, petals and lip.

- To create round and full form of sepals and petals with minimum fenestration and twists.

- To increase the length of inflorescence.

- To increase the number of flowers / inflorescence.

- To achieve compactness in flower facing on the spike.

- To develop hybrids showing correct mode of display.

- To extend blooming period.

- $\quad$ To produce miniature forms.

- To produce fragrant varieties.

- To produce flowers with longer vase life.

- To develop types suitable as pot plants.

- To develop hybrids insensitive to strict climatic regime.

- To develop hybrids resistance to biotic stress like diseases particularly to viruses.

\subsection{Selection of Parents}

Healthy parent plants are to be selected so that they can produce healthy seed pods with innumerable seeds. Selection of parents depend upon the aim of breeding and genetic affinity of the parental lines. Information on whether the parent performs well as pollen parent or seed parent, as well as the vigour and floriferousness of the parent are required as pre-breeding criteria. Knowledge of compatibility, chromosome number and behaviour of the parents are essential. Known ability of the parents to influence the character in its progeny will also be helpful. Very young plant or seedlings blooming first time should not be selected as the mother plant to bear the seed pod. A very healthy and 
vigorous plant can bear two to three seed pods without affecting the normal health of plant. A cross becomes successful if two different types of orchids are genetically related.

\subsection{Compatibility Analysis}

A thorough understanding of the compatibility relationships of the genera as well as species is essential for successful hybrid development. According to Lenz and Wimbler, 1959, many of the cases of the apparent self-incompatibility and cross sterility commonly encountered among orchid hybrids could be due to either of two causes hybrid sterility or polyploidy. Duncan and Curtis (1943) observed that the self incompatible orchids always have homomorphic, gametophytic and polyallelic incompatibility with stigmatic inhibition of pollen germination. The failure of fruit development in many reciprocal crosses hints at the operation of an unidirectional incompatibility in orchids (Devi and Deka, 1992).

\subsection{Breeding of Hybrids}

Many Indian species have obtained worldwide recognition in breeding programmes due to their inherent attractiveness coupled with their ability to transmit desirable characters to hybrids. Some of the leading species are Aerides multiflorum, Cymbidium devonianum, C. lowianum, C. tracyanum, C. elegans, Dendrobium aggregatum, Den. chrysotoxum, Den. formosum, Den. nobile, Paphiopedilum venustum, Vanda coerulea (Bose and Bhattacharjee, 1980).

\subsubsection{Cattleya}

The cattleya species like aurantiaca, bicolor, bowringiana, dowiana, forbesii, granulosa, guttata, intermedia, labiata, loddigesii, luteola, mossaie, triannaei, warneri etc. are extensively used for hybridization work. Moreover, the Cattleya has also been crossed with several other genera such as Berkeria, Brassavola, Broughtonia, Diacrinum, Domingoa, Epidendrum, Laelia, Laeliopsis, Schomburgkia, Sophronitis and produce multi-generic hybrids. The cattleya cultivars like 'Bob Betts', 'Bow Bells', 'Claesiana', 'Empress Bells', 'Enid’, 'Estette’, ‘General Patton', 'Henrietta Japhet’, 'Karae Lyn Sugiyama', 'Margaret Stewart', 'Nellie Roberts', 'Nigritian', 'Pearl Harbour’, ' Portica', 'Primma Donna'. 'Vesper Bells' are considered famous and are proven mother plants for breeding work. Cattleya dowiana and its variety 'aurea' have been of great importance in the development of the beautiful yellow flowered hybrids. In crosses with the coloured or alba forms of the Cattleya species, the yellow colour of $C$. dowiana acts as a recessive trait and does not appear in the first generation, the flower being coloured 
with anthocyanin pigments. In certain $\mathrm{F}_{2}$ populations involving $C$. dowiana, the plants segregate to give yellow, cream and white coloured flowers (Fenton, 1951). Mehlquist (1958) studied the inheritance of white flowers with coloured lip. He suggested a gene $\mathrm{P}$ to be responsible for this type of colouration due to interact with $\mathrm{C}$ and $\mathrm{R}$ genes.

The Cattleya alliance Laelia and Sophronitis are known for their bright colour contribution. The redness of many of the orchid hybrids were introduced from Sophronitis grandiflora. The flowers of this Sophronitis species are small and many of the resulting Sophrocattleya, Sophrolaelia and Sophrolaeliocattleya have comparatively small flowers. Northen (1949) observed that the gene for red is dominant, and when present in a homozygous condition it gives a beautiful clear red colour.

Intergeneric hybrids involving Brassavola give a very attractive fimbriated lip. The first Brassocattleya was bred as early as 1889 by Maron, in which Brassavola digbyana was combined with Cattleya, while the first Laeliocattleya was bred by Sanders in 1903 from a cross between Cattleya hardyana and Laelia pumilapratens. The first trigeneric hybrid Sophrolaeliocattleya was bred by Holfred in 1907 from a cross between Laeliocattleya Aureole and Sophronitis coccinea. A hybrid genera Potinara (which is a tetrageneric hybrid combining Cattleya, Laelia, Brassavola and Sophronitis) was registered for the first time in 1922 (Bhattacharjee and Das, 2008). The introduction of blue colour in Cattleya breeding was discussed by Granier, 2002. One of the prominent hybrids used extensively for blue Cattleya breeding is Laeliocattleya 'Canhamiana', a cross between $C$. mossiae and Laelia purpurea. Among the genus Brassavola, $B$. cucullata, B. cordata, B. nodosa and B. perrinii are extensively used in hybridization (Mathews, 1996). The large flowered Cattleya hybrids are the results of breeding involving fifteen Cattleya species, two Laelia and Brassavola digbyana (Herman, 1997). In Brassocattleya the varieties 'Deesse' and 'Hortland' are reported to produce many hybrids in Cattleya alliance. The trigeneric hybrid Brassolaeliocattleya are also well known for their varieties like 'Edwin Chong', 'Golden Myth', 'Herons Ghyll', 'Jane Helton', 'Malvern', 'Marjorie Frey', 'Mellow Glow', Molflora', 'Norman’s Bay', 'Nugget', etc which have produced many interesting hybrids. In Laeliocattleya are the varieties 'Charlesworthii', 'Easier Bonnet', 'Edgard Van Belle', 'Elissa', 'Grandee', 'Harold J Peterson', 'Ishtar', 'Morro Rock', 'Nugget', 'Pacific' 'Paradasio', 'Princess Margaret', 'S.J. Bracy', 'South Esk', 'Supervia', 'Twinkle Star', which are famous proven parent plants for hybridization work.

\subsubsection{Cymbidium}

Cymbidiums are highly valued as cut flowers as well as pot plants in the international florist trade. Innumerable numbers of hybrids have been evolved. The species like Cymbidium devonianum, C. ensifolium, C. erythrostylum, C. grandiflorum, C. hoosai, $C$. insigne, C. madidum, $C$. pumilum and $C$. tracyanum are successfully utilized for the development of many hybrids. Some of the hybrids like 'Balkis', 'Cleo 
Sheraton', 'Desiree A’logann', 'Early Bird', 'Joan of Arc', 'Kurun', 'Lucy’, 'Lustrous', 'Mayfair', 'Miretta', 'Nam Khan', 'October,',Oiso', 'Ortin', 'Redwood', 'Remus', 'Rio Rita', ‘Rosanna', ‘Shiraj', ‘Stanley Fouraker', ‘Swallow’ and 'Vieux Rose’ are outstanding and largely utilized as parent plants for production of many spectacular hybrids.

The species like $C$. pumilum, $C$. devonianum and $C$. ensifolium are small flowered types and cross easily with the large flowered Himalayan species. Most of the hybrids in Cymbidium evolved through the utilization eight of the large flowered species viz. Cymbidium iridioides (syn. C. giganteum), C. eburneum, C. hookerianum (syn. C. grandiflorum), C. sanderae, C. lowianum, C. tracyanum, C. insigne and C. erythrostylum).

In the case of Cymbidium 'Alexanderi', a cross between $C$. 'Eburneo-Lowianum' and $C$. insigne, the progenies of the cross were diploid, but the clone of the cross 'Westtonbrit' proved to be tetraploid. In fact this hybrid changed the world of cut flower cymbidiums. Cymbidium 'Alexanderi' was producing everything that was required where quality was concerned (Keith, 2000). This hybrid became popular because of its large white flowers and as a parent for pestal coloured popular hybrids.

The Japanese and Chinese species of Cymbidium are utilized for the breeding of miniature types. Miniature hybrids are good as pot plants and slightly tolerant to warmer conditions. The first miniature hybrid in Cymbidium evolved in England in the year 1944, and was a cross between C. 'Lousie Sander' x C. pumilum. The variety 'Lousie Sander' is a cross between 'Alexanderi' $\mathrm{x}$ 'Ceres'. $C$. munronianum has been used as parent in several breeding programmes for contributing scent characteristics to the offspring.

\subsubsection{Dendrobium}

Dendrobiums are very popular among the orchids throughout the world for higher productivity and floriferousness. These are well known as cut flowers and potted plants.

The Dendrobium species like aemulum, affine, aggregatum, aries, canaliculatum, chrysotoxum, compactum, d'albertisii, dalhousieanum, delicatum, dicuphum, forbesii, formosum, goldiei, gracilicaule, gracillimum, grantii, johnsoniae, kingianum, laxianthera, laxiflorum, leporium, macrophyllum, mirbellianum, nobile, odoardi, ostrinoglossum, phalaenopsis, primulinum, superbum, taurianum, tetragonum, toftii, tokai, trilamellatum, undulatum, veratifolum, violaceo-flavens and williamsonii are successfully utilized for hybridization programmes and produce many outstanding hybrids of special merit. Vacherot and Lecouffle of France were the pioneers of Dendrobium breeding. The nobile type (narrow petals) Dendrobiums of Eastern Himalayas and $D$. phalaenopsis (rounded petals) of eastern Asia were the most frequently used parents. Kuehnle et al (1997) observed that pigments comprised of cyanidin glycosides are the predominant pigments extracted from the lavender and purple Dendrobium. Kamemoto and Amore (1990) reported that a dominant gene P is responsible for lip 
colour or the semi-alba trait of white petals and sepals with coloured labellum, based on crosses between semi-alba $D$. dicuphum and white $D$. affine or white $D$. phalaenopsis var. compactum 'Mauna Kea'. According to Thammasiri et al (1986) yellows and greens in Dendrobium are due to carotenoids and chlorophylls. Improved yellow cultivars are contributed by triploidy. Kamemoto et al (1999) reported inbreeding depression, which is expressed as a loss in vigour and pollen degeneration in $D$. phalaenopsis and D. biggibum, but not found in D. antennatum. Several cycles of inbreeding and selection using an amphidiploid Dendrobium 'Jaquelyn Thomas' proved useful to increase flower size and lighten colour (Bobisud and Kamemoto, 1982). It also produced valuable stud plants when used subsequently in outcross to restore vigour. Colour has always been of prime importance in Dendrobium breeding ranging from chalky white to yellow, brown and intense crimson (Abraham and Vatsala, 1981).

For producing compact hybrids with short pseudobulbs to breed for potted plants D. carronii, $D$. canaliculatum, $D$. phalaenopsis, $D$. var. compactum, $D$. bigibbum var. compactum, Dendrobium 'Mini Gem' are suitable (Kuehnle, 2006). Kaiser (1993) suggested one parent of possible interest for breeding fragrant potted plants is $D$. d'albertisii; and out of the 140 species evaluated, 40 percent produced scents ranging from floral to fruity to herbaceous. Some of the outstanding varieties of Dendrobium used in further hybridization program and are recognized as proven parents are 'Agnes', 'Ann', 'American Beauty', Amethyst', 'Anouk', ‘Artur Elle’, 'Black Bountain', 'Caesar',

'Carol Ann', 'Claire Ayau', 'Concert', 'Constance', 'Dixon', 'Endeavour', 'Ethreal Kawamoto', ‘Ewa', ‘Gold Flush', ‘Gold Twist', ‘Helen Fukumara’, ‘Hula Girl’, 'Jaquelyn Thomas', 'karen Ono', 'Khaw Young Hong', 'Lady Fay', 'Lady Hamilton', 'Lady Nui', 'Lim Chong Min', 'Lynn Takiguchi', 'Maloe Kanya', 'Manoa Gold', 'Margi Thomas', 'Main Beauty', May Neal', 'Mustard', 'New Hawaii', 'Pale Face', 'Pompadour', 'Rose Chong', 'Shangrilla', Ursula', 'Valley King', 'Vera Patterson', 'Yellow Curls', and 'Yellow Jacket'.

\subsubsection{Odontoglossum}

This genus produces the finest flowers of all cool growing orchids. The Odontoglossum species like cirrhosum, crispum, hallii, pendulum, pulchellum are used for hybridization work. There are many hybrids of Odontoglossum on record and a large number are made with related genera like Aspasia, Cochlioda, Miltonia and Oncidium. The outstanding hybrids of Odontoglossum widely used as parents for production of further hybrids are 'Carroll', 'Ismene', 'Patnina' etc. (Bhattacharjee and De, 2003).

\subsubsection{Oncidium}

The orchid plants under this genus are known as 'Dancing Ladies' and 'Golden Showers' because of their showy alternatively shaped blossoms. Large numbers of 
Oncidium species are utilized for production of spectacular hybrids and most important species in this respect are henekenii, intermedium, lanceanum, leucochilum, marshallianum, pulchellum, retemeyerianum, splendidum, sylvestre, triquetrum, vericosum and variegatum. The genus is cross compatible with other genera like Aspasia, Brassia, Cochlioda, Comparettia, Gomesa, Macradenia, Miltonia, Odontoglossum, Rodriguezia, Trichocentrum, Trichopilia etc. and hence, many multi-generic hybrids have been evolved. Some of the outstanding hybrids which have proven worth as parent plants for production of more and more attractive hybrids are 'Angnes Ann', 'Ann Rosa', 'Catherine Wilson', 'Delight', 'Golden Glow', 'Helen Brown', 'Lovely’, 'Organ Mountains', 'St. Anne’, and 'Waikiki Sunset’ (Bhattacharjee and De, 2003).

\subsubsection{Paphiopedilum}

This is a remarkable genus of a magnificent group of orchids, commonly called 'Lady's Slipper' orchids. The cut flowers remain fresh in plain water for up to six weeks. Paphiopedilum rothschildianum is one of the most important species and has produced nearly 200 hybrids. Important species used in hybridization programmes are bellatulum, godfroyae and niveum. One of the most outstanding hybrids in this genus is 'Rolfei' which is a cross between Paph. rothschildianum and Paph bellatulum. Another important hybrid is Paph. 'Daisy Barclay', which was evolved from a cross between Paph. rothschildianum and Paph. godefroyae. The cross between Paph. rothschildianum and Paph. niveum created Paph. woluwense. An allelomorph in Paph. insigne, Paph. spicerianum and Paph. boxalli was reported by Hurst (1925). Rogersen (1991) has suggested that for breeding white coloured Paphiopedilum, species like insigne var. Sanderae, bellatulum and godefroyae are important and described the general principles governing the inheritance of the white flower colour in orchids, and specifically in the genus Paphiopedilum. Tu-Fu Philip Liu (2000) stated that the backbone of green and white albino forms was Paphiopedilum callosum var sanderae; for green breeding, Paph. 'Desert Spring, for yellow breeding promising clones are some hybrids of Paph. sukhakulii var. album, such as Paph. fairrieanum var. album; for white breeding Paph. charlesworthii var. album. Paphiopedilum is a cross compatible with Selenipedium and Phragmipedium.

\subsubsection{Phalaenopsis}

Phalaenopsis is highly valued for its long lasting cut flowers, pot plants and hanging baskets. Several species of Phalaenopsis utilized for the production of outstanding hybrids are amabilis, amboinensis, boxalli, buyssoniane, cornucervi, denevei, equestris, Esmeralda, fasciata, fimbriata, fuscata, grandiflora, lueddemanniana, lindenii, mannii, mariae, parishii, schilleriana, serpentilingua, stuartiana and violacea. Hybridization of Phalaenopsis mainly evolved around the development of pure whites, 
pure pinks and white with pink lips. P. amabilis, P. formosana and P. aphrodite were extensively used for production of outstanding white hybrids. For development of pink coloured hybrids like the lueddemanniana, sanderiana and schileriana figured prominently. White colours with pink lip was achieved in P. intermedia due to natural hybridization between $P$. aphrodite and P. equestris. According to Thomas (2001) all modern white Phalaenopsis are descendents of two species, P. amabilis and P. aphrodite. Phalaenopsis 'Doris' was bred in 1940 and is one of the most influential white hybrids. Yellow and red Phalaenopsis breeding started with a cross between $P$. 'Doris', and $P$. manni to produce $P$. 'Golden Louis'. Red Phalaenopsis breeding is generally accompanied by problems with fertility, flower size and low flower count. The first fertile and readily available red Phalaenopsis was 'Golden Buddha' (Ginsberg, 2000). Another recent trend in Phalaenopsis is breeding for blue flowers. The two species that formed the basis of blue Phalaenopsis breeding are Doritis pulcherrima var. coerulea and Phalaenopsis violacea var. coerulea (Mountford, 2001). Harper (1993) discussed the contribution made by Phalaenopsis stuartiana in the development of multiflora Phalaenopsis hybrids. Thomas (2001) reviewed the requirements for flower forms of commercial growers like strong self supporting erect inflorescences, long duration of blooms, compact plant size, wide temperature tolerance, disease resistance, firm substances and consistency of colours.

Selfing and backcrossing techniques have been found immensely beneficial in breeding for superior hybrids. The long continued inbreeding of Phalaenopsis sanderiana is a famous example leading eventually to superior clones. Multi-generic hybrids have been evolved by crossing Phalaenopsis with other genera like Aerides, Arachnis, Doritis, Neofinetia, Rhyncostylis, Renanthera and Vanda. Some of the hybrids of Phalaenopsis which have served as parent plants for production of many more outstanding hybrids are 'Aalsmeer Rose', 'Ann lovelace', 'Aristocrat', 'Barbara Bred', 'Big Chief', 'Cassango', 'Cast Iron Monarch', 'Chieftain', 'Cindy Brand', 'Doreen', 'Doris', 'Dos Pueblos', 'Elinor Shaffer', 'Elisa', 'Elwy Middleton', 'Fairway Park', 'Fenton Davis Slover', 'Gladys Red', 'Goleta', ‘Grace Palm, 'Hollywood', 'Hymen’, 'Intermedia', 'Joanna Magale', ‘ Junita’, ‘Judy Karleen', 'Kareen', 'Lachesis’, 'Lakme’, 'Loius Georgianna', 'Louis Market', 'Luzon', ‘Margaret Bean', 'Marmouset', 'Martha', 'Mild Red Karleen', 'Mrs’ J.W. Veitch', 'New Horizon', 'Palm Beach', 'Pasadena', 'Pink Vision', 'Pink Wave', 'Princes Grabce', 'Queen Emond', 'Radiant Glow', 'Reve Rose', 'Rosewell', Ruby Lips', Seretiny’, ‘Shivley Temple’, 'Susan Market', ‘Texas Star’ and 'Zada’.

\subsubsection{Vanda}

This genus bears attractive flowers which are often large, the colour of flower ranges from pure white to variegated pattern of brown, green, and bright pink to blue and purple. These are commercially important cut flowers used in international flower trade. The Vanda species which contributed for production of useful and showy 
hybrids are amnesiana, batemanni, coerulea, coerulescens, dearci, denisoniana, hookeriana, insignis, lamellata, loatica, limbata, liouvillei, luzonica, marvillii, parviflora, roeblingiana, roxburghii, sanderiana, spathulata, stuavis, sumatrana, teres and tricolor.

The first Vanda hybrid, 'Miss Joaquim', which developed from a cross between $V$. teres and $V$. hookeriana (Teoh Eng Soon, 1998). An albino form of Vanda 'Miss Joaquim' was produced by crossing the alba varieties of both the parents. Vanda 'Miss Joaquim' is said to have taken the form of $V$. hookeriana and the colour of $V$. teres (Tim Wing Yam, 2001). Fuchs (1997) reported that Vanda sanderiana and V. coerulea are the two important vandal species found in the background of most of the vandaceous hybrids. V. sanderiana gives full form, whereas V. coerulea imparts the rich blue violet colouration, lobely tessellation as well as the long inflorescence.

The genus Vanda is cross compatible with other allied groups like Aerides, Arachnis, Ascocentrum, Doritis, Neofinetia, Phalaenopsis, Renanthera, Trichoglottis and Vandopsis. Some of the important hybrids of Vanda which contributed as parent plants for production of many more hybrids are "Amoene', 'Betsy Summer', 'Bull Sutton', 'Eisenhower', 'Ellen Noa', 'Emily Notley’, 'Ernest', Fujinaga’, 'Frank Crook', 'Haledena', 'Helen Reynolds', 'Hilo Blue', ‘Honolulu’, 'Jennie Hashimoto', 'Josephine Van Bero', ‘Kapolio', ‘Manila', 'Manisaki’, 'Miss Joaquim', 'Noel’, ‘Nora Potter', 'Norbert Alphanso', ‘Onomea', 'Poepoe', 'Rubella', 'Ruby Prince', ‘Tan Chay Yan', ‘Tatzeri', ‘Trimerrill', 'Trisher', 'Venus' and 'Waipuna'.

\subsection{Polyploidy Breeding}

Polyploidy and introgressive hybridization played a major role in the development of orchid hybrids. In some genera like Cymbidium, Paphiopedilum, Phalaenopsis, Cattleya, Laelia, Sophronitis, polyploidy coupled with intergeneric compatibility has culminated in the formation of hybrid groups which show both greater size and hybrid vigour as compared to parental species. Most orchids have two basic sets of (diploid 2x) chromosomes. The most common form of polyploidy is the doubling of the chromosome number from diploid (2x) to tetraploid (4x). Tetraploid plants are more fertile and produce flowers of better texture, bigger size and more intense colouration. According to Abraham and Vatsala (1981), infertility in polyploids often results from pairing abnormalities during meiosis. Sterility is most frequently caused by triploidy, commonly encountered in many of the cultivated orchids. Kamemoto et al (1999) has described a strategy in which a triploid yellow, $D$. 'Mary Mak' was crossed to a diploid $D$. helix. Among a population of mostly aneuploids, several tetraploids were obtained for use in subsequent breeding.

Hawaiian breeders produced exciting tetraploid clones by repeated selfing of $V$. 'Miss Joaquim', which is a diploid $(2 \mathrm{n}=38)$. The most popular clones produced are 'Atherton', 'Juliet', 'Hula Girl', 'Wood Lawn' and 'Douglas'. Most of the subsequent $V$. 'Miss Joaquim', hybrids are based on these tetraploids. About 450 hybrids have 
been raised from Vanda, 'Miss Joaquim' (Tim Wing Yam, 2001). In Phaius tankervilliae, treatment of protocorms by colchicine treatment $(50 \mathrm{ppm})$ induced polyploidy. Doubling of chromosome number was associated with increased guard cell and stomatal size and height and weight of plants (Devi and Deka, 2000). According to Hedren et al (2000) diploid members of the genus Nigritella have sexual reproduction, whereas polyploidy members are characterized by agamospermy. The AFLP data support the general picture of polyploidy evolution in Dactylorhiza .i.e. that allotetraploid derivatives have arisen repeatedly as a result of hybridization between the two parental groups D. incarnata and D. maculata group (Hedren et al, 2001).

\subsection{Genetic Engineering}

Genetic engineering coupled with tissue culture technique provides a useful way to introduce specific genes into plants as evidenced by a successful introduction of improved protein quality, novel flower colour and disease, insect and pest resistance into various crops in the relatively short period of time. In orchids, the first report on genetic transformation was made by Kuehnle and Sugii (1992). Several gene transferred methods have been tested with Dendrobium such as particle bombardment (gene gun) (Kuehnle and Sugii, 1992, Chia et al, 1994), protein electro injection, seed imbibation and pollen tube mediated DNA transfer (Nan \& Kuehnle, 1995b). Among these, micro bombardment (Klein et al, 1987) was identified as highly suitable for Dendrobium based on high frequency recovery of transgenic plants. A co-cultivation method was standardized for transforming Phalaenopsis varieties in vitro with Agrobacterium tumefaciens using protocorm like bodies as explants (Hsieh et al, 1997). Yang et al (1999) and Yu et al (1999) exploited the protocorm like bodies (PLBs) to transform the orchid using particle bombardment in hybrids of Cymbidium and Dendrobium, respectively. Protocorm and PLB's of three genera Brassica, Cattleya and Doritaenopsis were genetically transformed via micro-projectile bombardment (Knapp et al, 2000).

Genetically transformed plants can be obtained by co-cultivation of Agrobacterium tumefaciens with cell clumps in Phalaenopsis orchid (Belarmino and Mii, 2000) and with their rhizome sections in Cymbidium niveomarginatum (Chen et al, 2002). A protocol was standardized to obtain a stable transgenic orchid (Dendrobium nobile) via Agrobacterium mediated transformation of PLBs (Men et al, 2003b). Transgenic orchid (Phalaenopsis cv. White Hikaru) plants were generated by inoculating a needle wounded PLB with Agrobacterium tumefaciens (Chai and Kim, 2004). The transformation of Phalaenopsis cv. Taisuco Crane protocorm like bodies (PLB's) by particle bombardment and Agrobacterium tumefaciens mediated transformation with beta-glucuronidase (GUS) fusion protein was studied by Chan et al (2003). Liau et al (2003) indicated that foreign DNA can successfully be integrated into the orchid genome and expressed transcriptionally and translationally in Oncidium orchid 
plants. Both genome breeding and molecular breeding approaches can be used concurrently in varietal development of Dendrobium as cut flowers and flowering potted plants. Chemical survey of Dendrobium species and hybrids has shows lavender cyanidin and peonidin to be the predominant anthocyanidin, and orange pelargonidin to be rare. Cloning and characterization of key anthocyanin biosynthetic genes such as of dihydro-flavanol 4-reductase enables more productive hybridization strategies to be implemented (Kuehnle et al, 2004). 